\title{
Serpentinite in the Śnieżnik Massif: petrology and ecological impact
}

\author{
Artur Pędziwiatr \\ Artur Pędziwiatr: University of Wrocław, Institute of Geological Sciences ul. Cybulskiego 32, 50-205 Wrocław, Poland
}

Record

Specific properties of serpentine soil in Żmijowiec result in the presence of endemic Asplenium adulterinum Milde and records the plant adaptation to extreme edaphic stress

\section{Abstract}

The paper presents a locality related to the occurrence of serpentinite body from the western slope of Żmijowiec in the Śnieżnik Massif. On the basis of field observations and numerous literature references, I provide a detailed geological description of this site and discuss the origin and tectonic settings of the serpentinite body. Apart from compelling geology, these rocks are site for ladder spleenwort, a rare species protected in Poland as well as in the European Union.

\section{Introduction}

Ultrabasic rocks crop out in Poland exclusively in Lower Silesia. They are usually partly or completely metamorphosed and referred to as serpentinites. The majority of these rocks form relatively large massifs associated with basic bodies surrounding the Góry Sowie Massif (i.e. Ślęża Massif, Szklary Massif, Nowa Ruda Massif; Figure 1). Mentioned massifs are considered as fragments of the same Early Devonian ophiolitic body called the CentralSudetic Ophiolite (e.g. Dubińska et al., 2004; Mazur et al., 2006; Kryza \& Pin, 2010). Nevertheless, small outcrops of ultrabasites, whose origin is still discussed, are stitching various crystalline rocks of the Sudetes (Gunia et al., 1998; Smulikowski et al., 1977). In this paper, I present some basic geological and ecological features from such a small outcrop of ultrabasites (serpentinites) located on Żmijowiec (Orlica-Śnieżnik Dome, OSD). Owing to exceptional chemical composition of ultrabasites and derived soils, they often harbour a specific plant community. The Żmijowiec site provides opportunity to study all aspects of the serpentinite occurrence: the serpentinite rock, soils derived from the rock and a rare species ladder spleenwort, a plant that grows only on serpentine soils.

\section{Outline geology of the Orlica-Śnieżnik Dome}

The OSD is located in the easternmost part of the Central Sudetes (Figure 1). It comprises a large orthogneiss body surrounded by the metamorphosed volcano-sedimentary succession composed mainly of mica schists, paragneisses, basic and acid metavolcanics and marbles. The orthogneiss represents deformed and metamorphosed granitic body dated, using single zircon evapo-
Keywords

serpentinite • the Orlica-Śnieżnik Dome • Śnieżnik Massif • Asplenium adulterinum

Received: 21 May 2015 Accepted: 28 September 2015

ration and SHRIMP methods, at 520-495 Ma (Turniak et al., 2000; Kröner et al., 2001; Lange et al., 2005). Supracrustal rocks represents the volcano-sedimentary succession which is traditionally divided into the Młynowiec monotonous Formation and the Stronie variegated Formation divided by thin horizon of the light Goszów quartzites and collectively labelled as the MłynowiecStronie Group (Don et al., 1990). The whole volcano-sedimentary sequence is believed to form continuous succession of either Neoproterozoic to Cambrian, based on micropaleontological evidence (e.g. Gunia, 1974; Gunia \& Wierzchołowski, 1979), or Cambrian to Ordovician age, based on detrital-zircon geochronology (Jastrzębski et al., 2010). However, the most recent isotopic data obtained by means of U-Pb SHRIMP dating on detrital zircons indicate that these rocks do not represent a single volcanosedimentary sequence but comprise different metasedimentary successions showing distinct maximum deposition ages: Neoproterozoic for the Młynowiec Formation, Early Cambrian for the Stronie Formation and latest Cambrian-Early Ordovician for the Goszów quartzites (Mazur et al., 2012).

Peridotites and serpentinites constitute small outcrops giving impression of stitching crystalline rocks of the OSD (Wierzchołowski, 1958). For instance, they occur in the Biała Lądecka Valley or in Żmijowiec (Figure 1B, 2A), the latter is the subject of this contribution.

\section{Description of the outcrop}

The outcrop is located in the western slope of Żmijowiec (Śnieżnik Massif; altitude $1117 \mathrm{~m}$ a.s.l.; Figure 2B). It is composed of two separate serpentinite crags. Larger unit is approximately $30 \mathrm{~m}$ wide and $20 \mathrm{~m}$ high, whereas second and smaller one is situated 


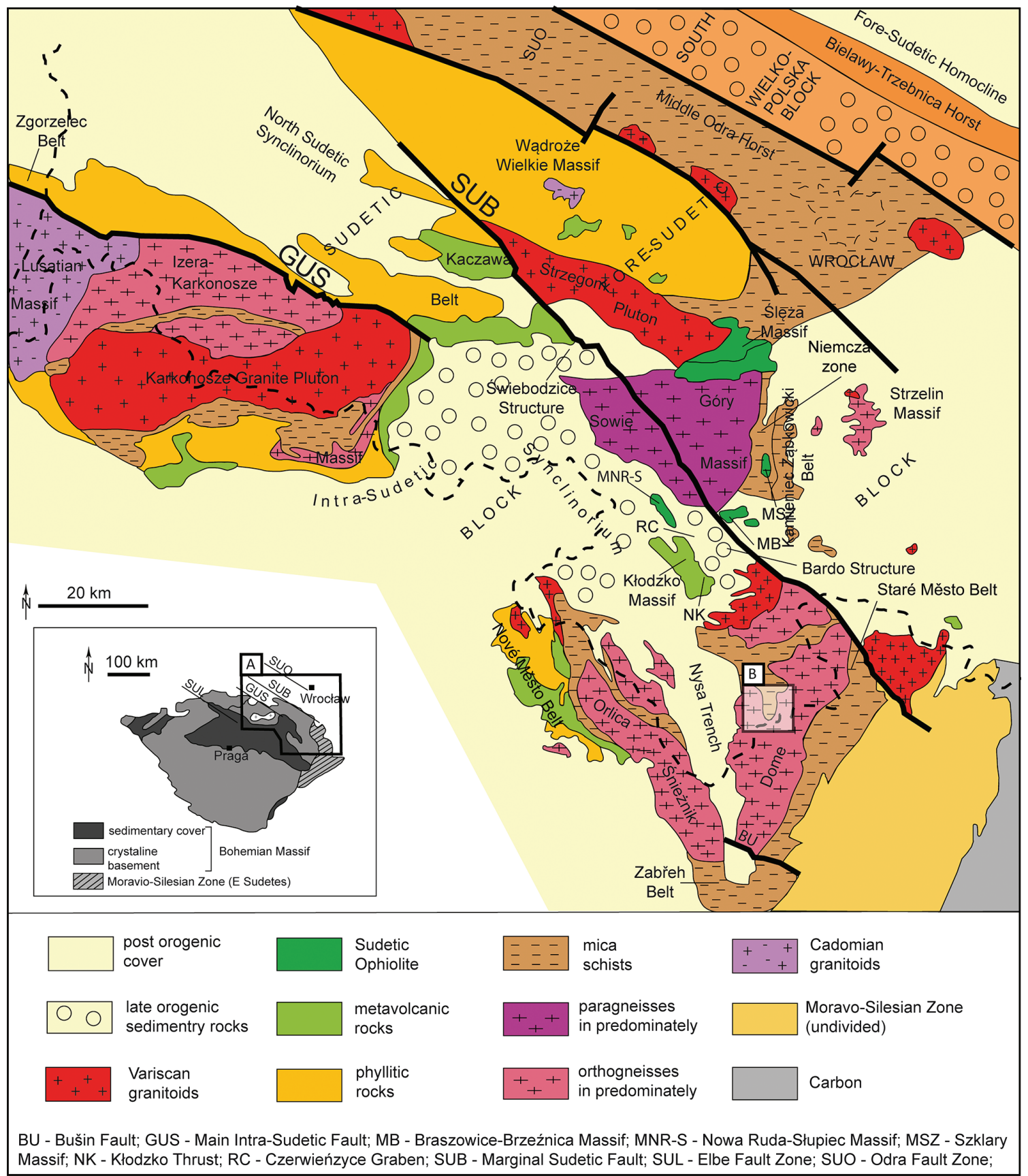

Figure 1. Tectonic map of the Lower Silesian Block: (a) the northeastern part of the Bohemian Massif with the Orlica-Śnieżnik Dome; (b) the area of occurrence of serpentinite in the Orlica-Śnieżnik Dome (after Żelaźniewicz et al., 2011).

several meters north-west of the main unit and is approximately $15 \mathrm{~m}$ wide and $5 \mathrm{~m}$ high.

The outcrop in Żmijowiec was already described by Bederke (1943) and Kasza (1964), who classified the rock from this locality as serpentinite. Further research by Smulikowski et al. (1977) distinguished four varieties of the Żmijowiec serpentinite: (a) typical serpentinite, (b) serpentinite with veins of talc, (c) serpentinite with abundant dolomite and (d) tremolite-rich serpentinites together with chlorite-tremolite rocks (the latter was also described by Wierzchołowski et al., 1958). The types are described in detail in the following:

1. Typical serpentinite (according to Smulikowski et al., 1977) is a massive dark green and nearly aphanitic rock consisting mainly of antigorite and minor olivine. Iron oxides are represented mainly by magnetite randomly distributed in groundmass (Figure 3 A, B). Rare talc or dolomitic veins crosscut the 


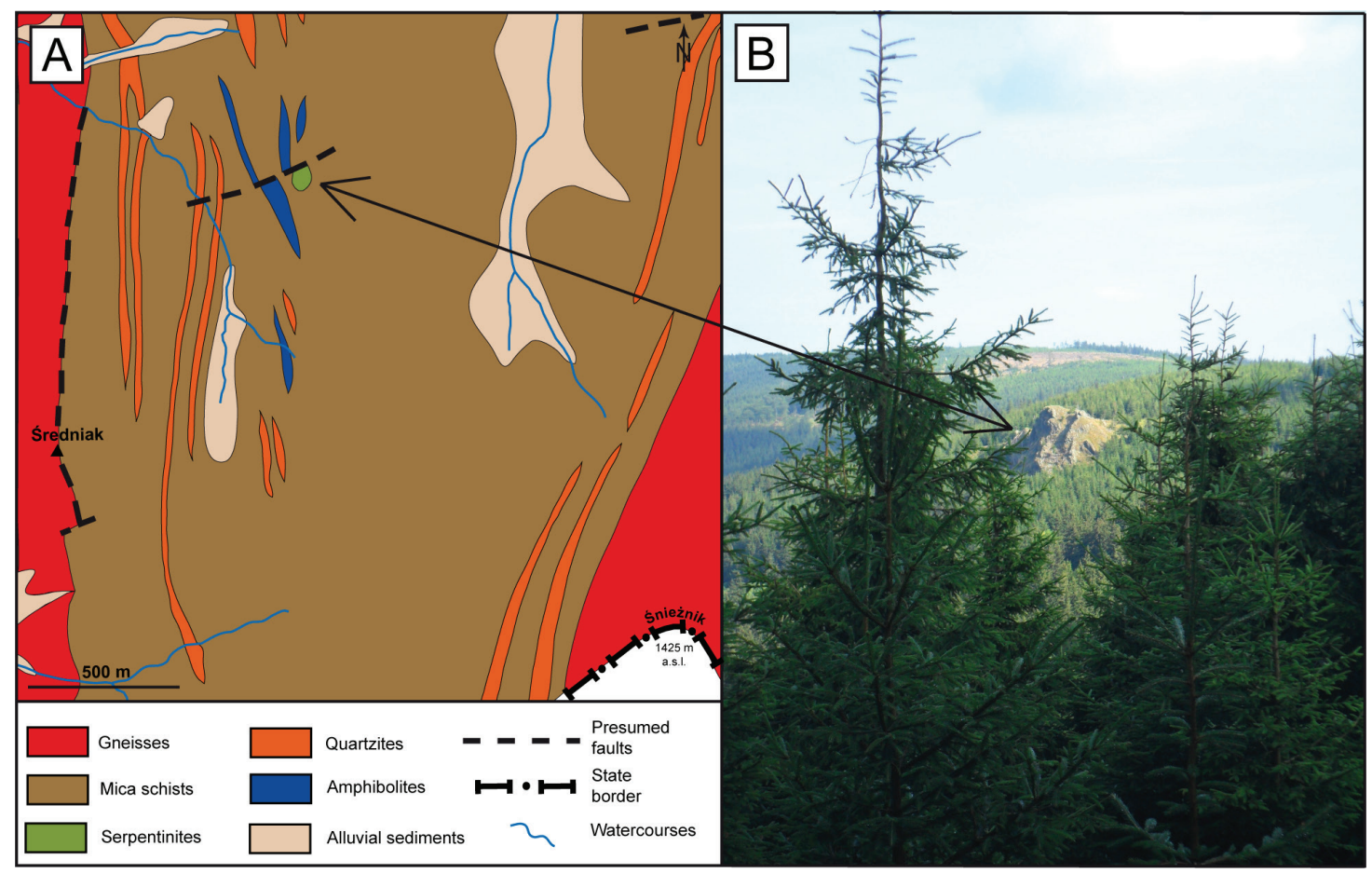

Figure 2. Study site: (a) geological map of Żmijowiec (after Frąckiewicz \& Teisseyre, (1973)); (b) view of the outcrop from red tourist trail.

serpentinite rock. Olivine was interpreted as secondary mineral by Smulikowski et al. (1977) and as relict igneous mineral by Gil (2010).

2. Serpentinite with veins of talc contains serpentine and talc as the main additional phase, whereas tremolite and dolomite are accessory phases.

3. Serpentinite with abundant dolomite contains talc and tremolite as accessory phases. Dolomite forms well-crystallised grains or microcrystalline streaks mixed with serpentine. Smulikowski et al. (1977) distinguished three varieties of this rock from greenish-black serpentinite to granular dolomite variety. These observations indicate that serpentine was replaced first by tremolite and later by dolomite during metasomatism.

4. The last type of serpentinites is represented by tremolite-rich variety. It is characterised by tremolite that fills fissures or is present as needles replacing antigorite. In some places, this type of serpentinites may be transformed into chlorite-tremolite rocks that are more abundant in iron oxides enriched in chromium (predominantly chromite; Smulikowski et al., 1977).

On the basis of textures of the serpentine group minerals, Gil (2010) divided serpentinites from Żmijowiec into serpentinites characterized by interlocking, intermediate and chrysotile-veined structure. Other ultrabasites are represented by chlorite (chloritetremolite) rock, uralitized orthopyroxenite and metaharzburgite. Serpentinites from Żmijowiec contain elevated amounts of $\mathrm{Ni}, \mathrm{Cr}$ and $\mathrm{Co}$, which reflect the primary composition of the rock and abundance of mafic minerals enriched in these elements, that is, olivine and orthopyroxene. Enrichment in $\mathrm{Ca}$, reflected by higher amounts of dolomite and tremolite in the rock, is due to the presence of hydrothermal solutions during late stage of metamorphism (Smulikowski et al., 1977).

Smulikowski et al. (1977) distinguished several types of country rocks surrounding the outcrop represented by zoisite-hornblende erlan, talc rock and amphibolite. Erlan was interpreted as a product of metamorphism of marly-dolomitic sediments in the amphibolite facies (Smulikowski et al., 1977). Alternatively, Gil (2010) classified this rock as metaharzburgite because of the presence of olivine and orthopyroxene. Additionally to previously described country rocks, Gil (2010) also distinguished biotite amphibolite with feldspar pegmatite, quartzite and micaceous schist lenses.

\section{The origin and tectonic interpretation}

Smulikowski et al. (1977) suggested that the Żmijowiec serpentinite represents ultrabasic magma, which was crystallised in crust and subsequently serpentinised. Afterwards, serpentine body was placed tectonically between amphibolites. Finally, rocks were subjected to metasomatism, cut by fissures and filled by secondary minerals (antigorite, chrysotile, talc, tremolite, dolomite as well as rare olivine).

On the basis of the depleted chemical character of the serpentinite (low contents of incompatible elements) and lack of clinopy- 


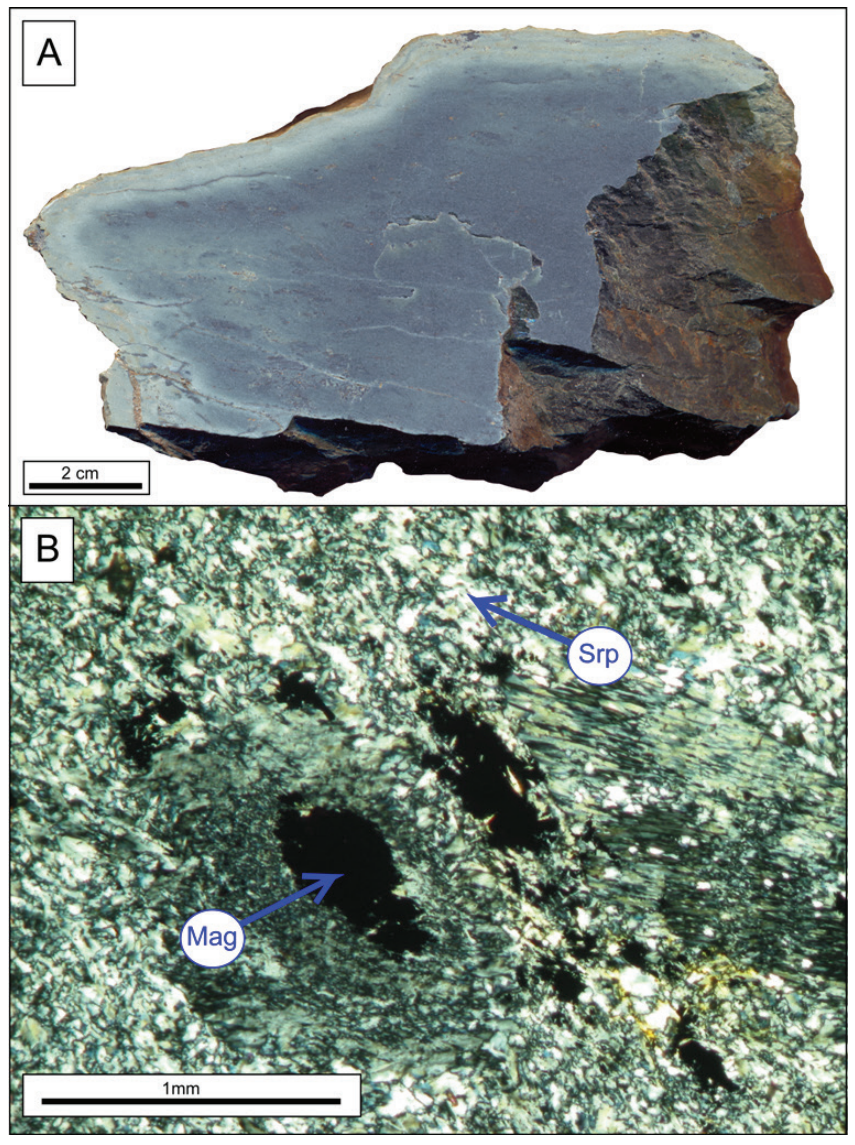

Figure 3. Serpentinite from Żmijowiec: (a) typical sample of the rock from the outcrop; (b) serpentinite under polarizing microscope (crossed nicols; Srp, serpentine; Mag, magnetite).

roxene remnants in the rock Gil (2010) suggested that the most probable protolith of the Żmijowiec serpentinite was harzburgite, dunite and orthopyroxenite. The protolith was subsequently placed tectonically among sedimentary rocks represented probably by tufs intercalated with clay-mudstone deposits. The maximum age of deposition is dated on circa $530 \mathrm{Ma}$ (Mazur et al., 2012), which suggests that the emplacement of the protolith took place after $530 \mathrm{Ma}$. Afterwards, protolith was metasomatised and metamorphosed under the conditions of the amphibolite facies during Variscan Orogeny. In the final stage chrysotile veins crystallized during retrograde metamorphism in the sub-greenschist facies conditions (Gil, 2010).

Further constraints on the age of the Żmijowiec serpentinite come from the observation of metamorphic structures. Serpentinites, amphibolites and other rocks of the Stronie Formation are characterised by similarly oriented planar deformation structures (Gil, 2010). It suggests that serpentinites were deformed and metamorphosed during the same tectono-metamorphic event as other rocks of the Stronie Formation (Gil, 2010). The main metamorphic event in the OSD is dated on circa 340-320 Ma based on various isotopic methods, for example, ${ }^{40} \mathrm{Ar} /{ }^{39} \mathrm{Ar}$ method (Stelten-

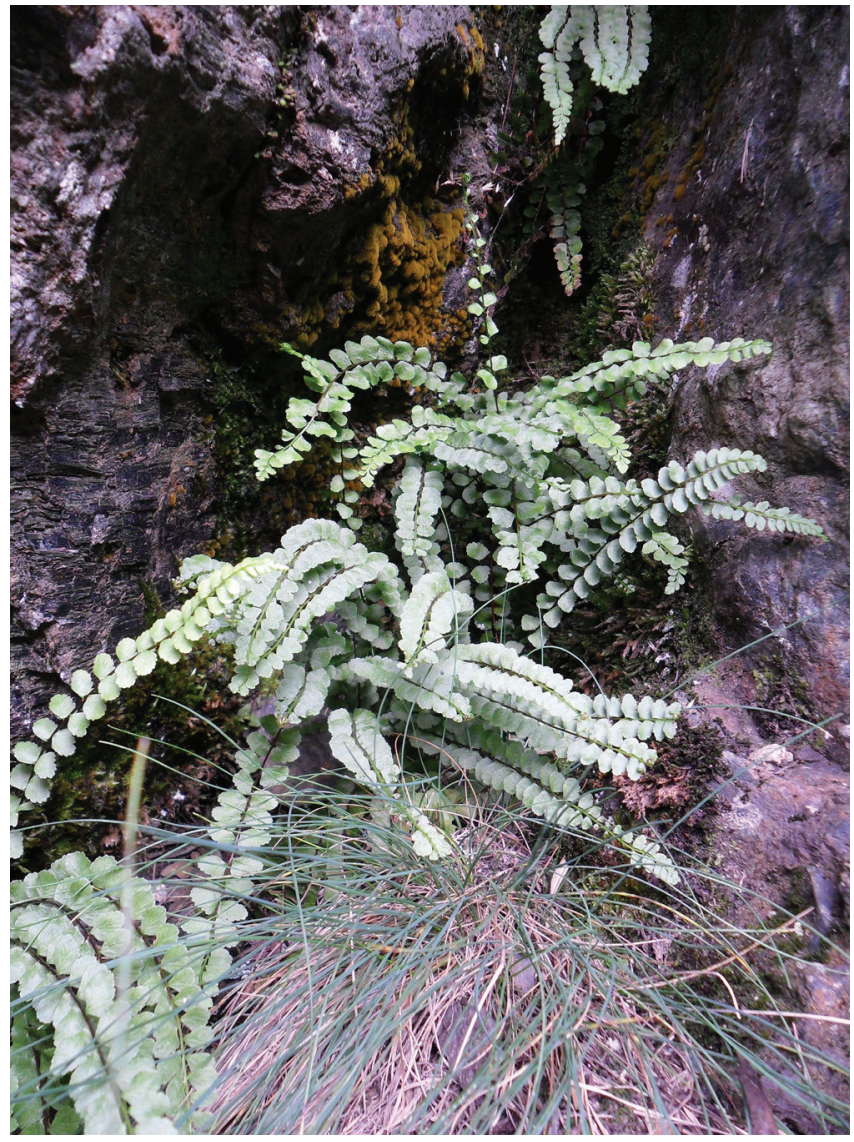

Figure 4. Ladder spleenwort Asplenium adulterinum in Żmijowiec at the beginning of May in 2010.

pohl et al., 1993; Maluski et al., 1995; Gordon et al., 2005; Chopin et al., 2012). This suggests that the protolith of the Żmijowiec serpentinites was emplaced within the rocks of Stronie formation before $330 \mathrm{Ma}$ (Gil, 2010). On the other hand, talc veins were not deformed and, therefore, their formation postdates the metamorphic event at $330 \mathrm{Ma}$.

\section{Ladder spleenwort $A$. adulterinum Milde - rare and endangered species related with ultrabasic rocks}

Ladder spleenwort grows mainly on ultrabasic rocks and is extremely rare in other habitats. The taxa was considered as European endemit, but recently new position of this plant was discovered in Canada (Klinkenberg, 2014). Ladder spleenwort grows usually on infertile soils, for example, characterised by elevated concentrations of $\mathrm{Ni}, \mathrm{Cr}$ and $\mathrm{Co}$, low Ca-to-Mg ratio and low concentrations of other macro elements - a typical features of serpentine soils (Figure 4).

Ladder spleenwort $A$. adulterinum Milde (syn.: Asplenium fallax (Heufler) Dorfler, Asplenium viride Huds. var. fallax Heufler, A. viride 


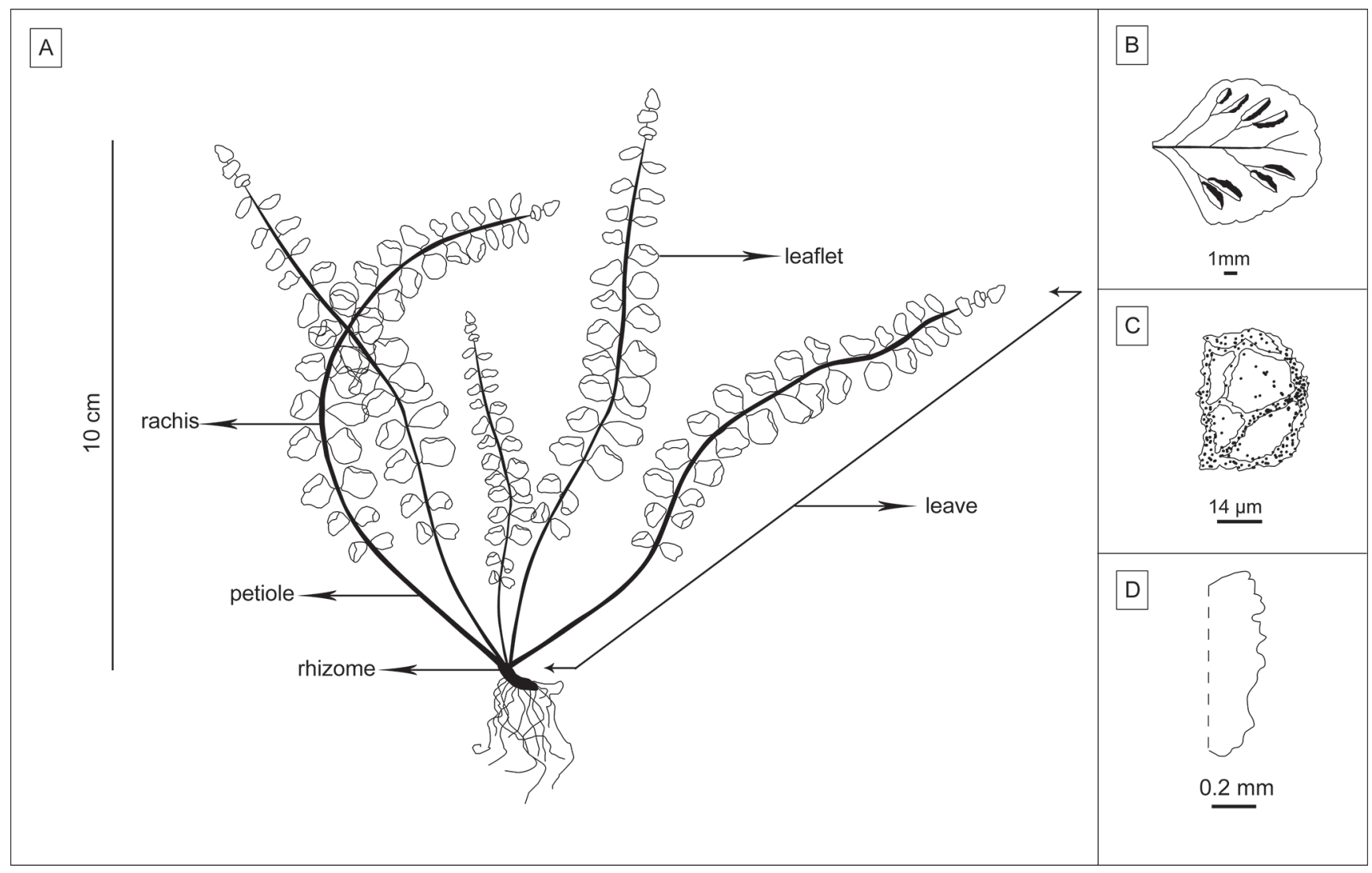

Figure 5. Ladder spleenwort Asplenium adulterinum: (a) morphological structure of the taxon; (b) the bottom side of the leaflet with sorus; (c) shape of the single spore; (d) shape of the indusium (after Karpowicz, 1963).

Huds. var. adulterinum (Milde) Wünsche) is a fern (Aspleniaceae) formed as a result of the intersection of the Asplenium trichomanes and A. viride (Karpowicz, 1963; Lovis \& Reichstein, 1968; Reichstein, 1981). Species consists of several individually pinnate leaves up to $25 \mathrm{~cm}$, which grow from short rhizome. Single leave consists of petiole, rachis and leaflets arranged on the rachis (Figure 5A). Taxonomic feature to recognise ladder spleenwort is a colour of petiole and rachis. In mature leaves, petiole and the lower part of rachis are brown coloured; however, the peak of rachis is green. Additionally, the bottom side of the petiole and rachis have recess (shallow'trough'). Fan-shaped leaflet are attached perpendicularly to the rachis by means of short petioles. Spores (bean-shaped) form sorus covered by indusium and occur on the bottom side of the leaflets (Karpowicz, 1963 and references therein).

Phytosociological studies indicate that $A$. adulterinum constitutes characteristic species for: $\mathrm{Cl}$. Asplenietea trichomanis (Br.-Bl. in Meier \& Br.-BI. 1934) Oberd. 1977; O. Androsacetalia vandellii Br.Bl. in Meier \& Br.-Bl. 1934 corr. Br.-BI. 1948; All. Asplenion serpentini Br.-Bl. \& R.Tx. 1943 ex Eggler 1955; Ass. Asplenietum serpentini Gauckler 1954 (Świerkosz, 2004).

A. adulterinum occurs in Poland only in Lower Silesia (Żołnierz et al., 2008). The total number of specimens is only 490 . The highest abundance was observed in the Kiełczyńskie Hills, and Żmijowiec has the smallest population in Poland (10 specimens; Żołnierz et al., 2008). The Żmijowiec location is also the highest position above sea level, where the plant was observed.

The taxon is listed in the European Union's 'habitat directive' in Appendix II and IV (code 4066; Directive, 1992). It means that the plant requires strict protection and protection needs Special Areas of Conservation appointment. Habitat of ladder spleenwort is also listed in the legal act (Appendix I, code 8220: siliceous rocky slopes with chasmophytic vegetation). In Poland, $A$. adulterinum is under strict protection and additionally has $30-\mathrm{m}$ protective zones from the borders of the position (Regulation of the Environment Minister, 2014). Plant is listed also in Polish 'red book' and 'red list' for Lower Silesia. Its status of threat is EN (endangered) and CR (critical), respectively (Kaźmierczakowa et al., 2014; Kącki, 2003).

\section{Acknowledgements}

This work was partially funded by the Polish National Science Centre (Project: 2012/05/D/ST10/00529). The author is grateful to anonymous reviewers, editor in chief and associate editor for critical comments on the earlier version of the manuscript. 


\section{References}

[1] Bederke E. 1943. Ein Profil durch das Grundgebirge der Grafschaft Glatz. Sonderdruck aus der Geologische Rundschau, 34: 6-9.

[2] Chopin F., Schulmann K., Skrzypek E., Dujardin J.R., Lehmann J., Martelat J.E., Lexa O., Corsini M., Edel J.B., Štípská P., Pitra P. 2012. Crustal influx, indentation, ductile thinning and gravity redistribution in a continental wedge: building a Moldanubian mantled gneiss dome with underthrust Saxothuringian material (European Variscan belt). Tectonics, 31: 1-27.

[3] Directive 1992. Council directive 92/43/EEC of 21 May 1992 on the conservation of natural habitats and of wild fauna and flora. OJ L 206, 22.7.1992: 1-66.

[4] Don J., Dumicz M., Wojciechowska I., Żelaźniewicz A. 1990. Lithology and tectonics of the Orlica-Śnieżnik Dome, Sudetes - recent state of knowledge. Neues Jahrbuch für Geologie und Paläontologie - Abhandlungen, 179: 159-188.

[5] Dubińska E., Bylina P., Kozłowski A., Wolfgang D., Nejbert K., Schastok J., Kulicki C. 2004. U-Pb dating of serpentinization: hydrothermal zircon from a metasomatic rodingite shell (Sudetic ophiolite, SW Poland). Chem. Geol., 203: 183-203.

[6] Frąckiewicz W., Teisseyre H. 1973. Szczegółowa Mapa Geologiczna Sudetów (1:25 000) Arkusz Międzygórze, Siemiatycka D. (ed.) Wydawnictwa geologiczne.

[7] Gil G. 2010. Charakterystyka petrograficzna ultrabazytów z okolic Kletna. [MS thesis], University of Wrocław: 1-104.

[8] Gordon S.M., Schneider D.A., Manecki M., Holm D.K. 2005. Exhumation and metamorphism of an ultrahigh-grade terrane: geochronometric investigations of Sudete Mountains (Bohemia), Poland and Czech Republic. J. Geol. Soc. Lond., 162: 841-855.

[9] Gunia P., Ziółkowska-Kozdrój M., Kozdrój W. 1998. New geochemistry data of ultrabasic rocks from eastern surroundings of the Karkonosze granite intrusion (Sudetes, SW Poland). B. Pol. Acad. Sci-Earth Sci., 46: 93-108.

[10] Gunia T., Wierzchołowski B. 1979. Mikroproblematyki z paragnejsów Gór Bystrzyckich (Sudety). Geologia Sudetica, 14: 7-24.

[11] Gunia T. 1974. Mikroflora prekambryjskich wapieni okolic DusznikZdroju (Sudety Środkowe). Rocz. Pol. Tow. Geol., 44: 71-76.

[12] Jastrzębski M., Żelaźniewicz A., Nowak I., Murtezi M., Larionov A.N. 2010. Protolith age and provenance of metasedimentary rocks in Variscan allochthon units: U-Pb SHRIMP zircon data from the OrlicaŚnieżnik Dome, West Sudetes. Geol. Mag., 147: 416-433.

[13] Karpowicz W. 1963. Paprocie na serpentynitach w Polsce. Fragmenta Floristica et Geobotanica, 10: 3-58.

[14] Kasza L. 1964. Budowa geologiczna górnego dorzecza Białej Lądeckiej. Geologia Sudetica, 1: 119-167.

[15] Kaźmierczakowa R., Zarzycki K., Mirek Z. 2014. Polska Czerwona Księga Roślin. Paprotniki i Rośliny Kwiatowe, 3rd edition, Władysław Szafer Institute of Botany of the Polish Academy of Sciences, Kraków: $1-895$.

[16] Kącki Z. (ed.). 2003. Zagrożone Gatunki Flory Naczyniowej Dolnego Śląsa, Institute of Plant Biology, Polskie Towarzystwo Przyjaciół Przyrody Pro Natura, Wrocław: 1-245.

[17] Klinkenberg B. 2014. E-Flora BC: Electronic Atlas of the Plants of British Columbia. [http://linnet.geog.ubc.ca/Atlas/Atlas.aspx?sciname=
Aspleniumadulterinum\&redblue=Both\&lifeform $=5]$, accessed: 27.11.2014.

[18] Kröner A., Jaeckel P., Hegner E., Opletal M. 2001. Single zircon ages and whole rock $\mathrm{Nd}$ isotopic systematics of early Paleozoic granitoid gneisses from the Czech and Polish Sudetes (Jizerské hory, Krkonoše Mountains and Orlice-Sněžník Complex). Int. J. Earth Sci., 90: 304-324.

[19] Kryza R., Pin C. 2010. The Central-Sudetic ophiolites (SW Poland): Petrogenetic issues, geochronology and paleotectonic implications. Gondwana. Res., 17: 292-305.

[20] Lange U., Bröcker M., Armrstrong R., Żelaźniewicz A., Trapp E., Mezger K. 2005. The orthogneisses of the Orlica-Śnieżnik complex (West Sudetes, Poland): geochemical characteristics, the importance of pre-Variscan migmatization and constraints on the cooling history. J. Geol. Soc. (London), 162: 973-984.

[21] Lovis J.D., Reichstein T. 1968. Über das spontane Entstehen von Asplenium adulterinum aus einem natürlichen Bastard. Naturwissenschaften, 55, 3: 117-120.

[22] Maluski, H., Rajlich P., Souček J. 1995. Pre-Variscan, Variscan and early Alpine thermo-tectonic history of the north-eastern Bohemian Massif: Ar 40/Ar39Ar study. Geol. Rundsch., 84: 345-358.

[23] Mazur S., Szczepański J., Turniak K., McNaughton J.N. 2012. Location of the Rheic suture in the eastern Bohemian Massif: evidence from detrital zircon data. Terra Nova, 24: 199-206.

[24] Mazur S., Aleksandrowski P., Kryza R., Oberc-Dziedzic T. 2006. The Variscan Orogen in Poland. Geol. Quart., 50: 89-118.

[25] Regulation of the Environment Minister. 2014. Rozporządzenie Ministra Środowiska z dnia 9 października 2014 roku w sprawie ochrony gatunkowej roślin. Dz. U. 2014 nr 0 poz. 1409: 1-37.

[26] Reichstein T. 1981. Hybrids in European Aspleniaceae (Pteridophyta). Bot. Helv., 91: 81-139.

[27] Smulikowski K., Smulikowski W., Bakun-Czubarow N. 1977. Serpentinite stock from the vicinity of mount Śnieżnik (Sudetes). Archiwum Mineralogiczne, 33: 5-35.

[28] Steltenpohl M.G., Cymerman Z., Krogh E.J., Kunk J.M. 1993. Exhumation of eclogitized continental basement during Variscan lithospheric delamination and gravitational collapse, Sudety Mountains, Poland. Geology, 21, 12: 1111-1114.

[29] Świerkosz K. 2004. Notes of the syntaxonomy of the Asplenietea trichomanis class in Poland. Polish. Bot. J., 49: 203-213.

[30] Turniak K., Mazur S., Wysoczański R. 2000. SHRIMP zircon geochronology and geochemistry of the Orlica-Śnieżnik gneisses (Variscan belt of Central Europe) and their tectonic implications. Geodin. Acta., 13: $1-20$.

[31] Wierzchołowski B., 1958. Skały ultrafemiczne okolic Bielic w Sudetach Wschodnich. Archiwum Mineralogiczne, 22: 401-431.

[32] Żelaźniewicz A., Aleksandrowski P., Buła Z., Karnkowski P.H., Konon A., Oszczypko N., Ślączka A., Żaba J., Żytko K. 2011. Regionalizacja Tektoniczna Polski, Komitet Nauk Geologicznych PAN, Wrocław: 1-60.

[33] Żołnierz L., Kromer K., Świerkosz K. 2008. Ladder spleenwort (Asplenium adulterinum Milde) in Poland - distribution, population state and conservation plan framework. [In:] Szczęśniak E., Gola E. (eds.) Club Mosses, Horsetails and Ferns in Poland - Resources and Protection, Polish Botanical Society and Institute of Plant Biology, University of Wrocław, Wrocław: 29-45. 